\title{
The Religiosity of Japanese Migrants in the Czech Republic
}

\author{
Petra Tlcimukova \\ Palacky University, Olomouc, Czech Republic \\ Email: petra.tlcimukova@upol.cz
}

Received 1 August 2013; revised 9 September 2013; accepted 16 September 2013

Copyright (c) 2014 Petra Tlcimukova. This is an open access article distributed under the Creative Commons Attribution License, which permits unrestricted use, distribution, and reproduction in any medium, provided the original work is properly cited. In accordance of the Creative Commons Attribution License all Copyrights (C) 2014 are reserved for SCIRP and the owner of the intellectual property Petra Tlcimukova. All Copyright (C) 2014 are guarded by law and by SCIRP as a guardian.

\section{Abstract}

This study examines the role of religion in lives of the Japanese migrants in the Czech Republic. Scholars have been dealing with issues concerning both the religiosity and migration for a long time. The contemporary sociology of religion offers various theoretical and methodological tools to approach both social phenomena; nevertheless, regarding the transformative character of both of them, it remains difficult to characterize the nexus of the various modes of religiosity and migration development. Based on critics of contemporary research on migrants' religiosity, I propose a qualitative approach that builds upon the postulates of theories of transnationalism and draws on Jean-Claude Kaufmann's method of understanding interviews. The method of gaining and analysing the interviews conducted with the Japanese living long-term in the Czech Republic allowed me to observe the process of religious identity construction, or in other words to uncover the deeper levels of claims concerning their relationship with religion. The results of my empirical investigation and analysis show that 1) not all migrants create transnational identities, 2) the method of understanding interview allowed some respondents to construct their own individualized and fragmented religious identities, 3) not all religious identities of migrants can be interpreted as transnational.

\section{Keywords}

Japanese Migrants; Religious Identities; Transnationalism; Complementary Research Attitudes; Transnational Religious Identity

\section{Introduction}

In the last decades, there has been a lot of academic attention paid to migration processes and its impact on dif- 
ferent social systems. Dealing with migration, it examined not only the human and subject transmission, but also the delocalization of values and thoughts. Many scholars try to reflect the developmental dynamics which were brought about by globalization, pluralistic character of societies and free market economy. Migration is an inherent part of these changes, its cause and effect. By no means is the Japanese global presence a new phenomenon, it is still as yet an under researched one.

Cultural and religious transformation in contemporary societies also can be regarded as one of the impacts of the migration process on a global scale. Philosophers, historians, sociologists of religion or scholars of the study of religions have been dealing with issues concerning the transformation of religious thought, the role of religion in societies, religious missionaries, minorities, transmission etc. Many interesting books and studies have been published on the religious traditions in Japan or religiosity of the Japanese. Academic reflections on the Japanese relationship with religion exaggerate many poignant theoretic-methodological questions concerning the sociological study of religiosity, some of which may be: ethic versus Emic research, the definition of religion, the disjunction of the secular and religious social spheres etc. [1].

Today, both migration and religious studies are theoretically and methodologically heterogeneous in principle. They both offer various approaches and questions for scholars to deal with. The topic of religion and religiosity thus serves, as is the case with migration, as a broad area of research where an accurately defined framework to operate is one the most important, however, for many are not unproblematic, demands.

As the title itself suggests, it is the aim of this study to examine the role that religion has in lives of Japanese migrants in the Czech Republic. The next pages present the outcomes of my field research undertaken during the autumn in 2009 and the summer in 2012. It also aims to give a sociological reflection of the migration and religion nexus on the theoretical and methodological level of research; for one of my intention was to find an appropriate framework to reveal the bilateral relationship of these two phenomena. The study examines the role of religion in lives of Japanese migrants in the Czech Republic. It tries in particular to give answers to the questions concerning the significance of religion in lives of Japanese long-term residents in the Czech Republic as it also reveals its transnationally/locally determined character.

Within the framework of the theories of transnationalism, I re-construct the trajectories of the migrants' religious identities (i.e. I understand the religious identities to be organic-cultural flows) [2, p. 54]. Simultaneously, using the method of understanding interview, I detect that fragments of both institutionalized and individualized religious identities function transnationally and are strictly locally bounded.

\section{Contemporary Research on Japanese Migration and Religiosity}

There have been several important scholarly attempts in the social sciences to capture and define the Japanese global presence along with its socio-cultural impact on the local environment, and vice versa. Harumi Befu has proposed the concept of "globalizing Japan" which denounces the traditionally conceived globalization movements from West to East and draws attention to the westerly oriented flows of the (Japanese) influences [3]. Nabuko Adachi is, among other topics, concerned with the ethnicity of the Japanese in contemporary societies. Leaving the primordial image of stabile ethnic identity [4], she employs the perspective of theories of transnationalism and describes the ethnic identity as a constantly negotiated dynamic concept which arises on the basis of developing social relations and transforming socio-cultural values [5]. These and other studies aim to provide the empirical evidence as well as to create a theoretical framework to the globally present Japanese diaspora by contextualizing the historical and social significance which it has reached in the last one hundred fifty years.

To help us better understand the phenomenon itself, how can we categorize the Japanese outside of Japan? Focusing on the purpose of migration, Fujita comes up with a new type of migrant- "a cultural migrant"-who leaves Japan to devote his or herself to the arts, languages etc. behind the boarders of his or her country of origin. Along with four other "classical" categories of Japanese migrants-male company employees and their families, female migrants, college students and entrepreneurs_cultural migrants are typical representatives of Japanese global migrants [6, p. 5].

What is striking about the studies dealing with Japanese migrants is foremost the eminent interest of scholars in what can be called the forming of ethnic identity in specific social contexts ${ }^{1}$. However, we should not forget to ask what the concept of ethnic identity stands for. One of the aspects which forms the ethnic identity of the Japanese abroad and has an impact on the socio-cultural sphere of the host countries at the same time is indeed

${ }^{1}$ The Japanese term nihonjinron that denotes the specifics of Japanese ethnicity is usually translated into English as Japaneseness. 
religion. How do contemporary researchers conceptualize the religion of Japanese migrants?

"Historically, as soon as Japanese began emigrating in nineteenth century, they took their religion with them" [3, p. 14], writes Befu when describing how different schools of Buddhism and also Shinto were successfully accommodated in both Americas. Hence, the so-called Japanese religion participates (via Japanese actors) in the Japanese cultural diffusion where Befu encounters Japanese pop-culture, martial arts, comics etc. In this process, the Japanese "new" religions have a significant role. These religions enter the Western socio-religious context with the time of the first Japanese migrants' encounter with the Western countries. Nevertheless, "entirely apart from immigrant-sponsored religion, Japanese religion has also spread among non-Japanese” [3, p. 14].

The importance of religion in the process of constructing the migrants' identity is emphasized in Yoshie Matsue's study. Analyzing the adaptation of Brazilian Nikkei (the Japanese migrants' descendants who were born abroad) she focuses on the members of the Catholic Church and Soka Gakkai International $[7,8]$. According to her findings, membership of the Japanese to religious organisation plays a crucial role in adaptation since the cultural-religious traditions construct the ethnic identity [7, p. 124].

In as much as we can be positive about the scholarly attempts to empirically and theoretically grasp and research the trajectories of Japanese world-wide migration, integration and in some cases also the role of religion, we should be aware of the black spot that remains concerning the Japanese presence in a European (and to a lesser extent Czech) context where this subject has not yet awoken much academic attention.

\section{The Czech Republic-Religiosity of the Czechs and the Situation for Foreigners}

The end of the Communist period brought about a crucial transformation in Czech society. A state-controlled economy changed into a free market based economy and a single-party based political system transformed into a pluralistic democracy. Religiously independent, secularized policy replaced the anti-religious state agenda and the country opened up itself to the free movement of goods as well as persons. More than twenty years have passed; however, it is still a challenge for both citizens and scholars to interpret the country as something other than atheistic and ethnically homogenous. Quantitative data shows the factual decrease in religious affiliation of Czech citizens (Table 1). At the same time, the research on individualized religiosity conducted so far in the Czech Republic [9, p. 196-202] shows it might be useful to turn our sociological attention to this under-researched and rich area, to shift our sociological imagination to concepts as for example fragmentary religious identity [10, p. 33]. As well as the religiosity of Czechs remaining largely unexplored, we have only a little evidence on the role of religion in the lives of foreigners. On a long-term scale, the data present Ukrainians $(117,810)$, Slovaks $(84,380)$, Vietnamese $(53,110)$ and Russians $(36,055)$ as the most prevalent foreign citizens living in the Czech Republic (Figure 1). Although quantitatively approached, the presence of foreigners and thus also the impact of foreigners' religiosity on Czech society might seem marginal, a qualitative perspective can reveal important processes proceeding on a micro-level. In any case, we can say that during the last two decades the Czech Republic has officially and overly become a heterogeneous country in terms of ethnical and religious diversity of non-traditional groups ${ }^{2}$. And scholars should take that into account properly.

\section{Specifics of the Japanese Presence in Czech Republic}

Regarding the Japanese in the Czech Republic, the quantitative data shows a slightly decreasing number during the last few years which is but a general phenomenon. The last census in 2011 showed the total number of Japanese is 1448 . The proportion of female and male is balanced while there is a prevalence of permanent stays in the case of women. Their presence generally has a metropolitan character, although the proportional percentage of migrants is spread around the country. Foremost, the Japanese activity is by many connected to specific socio-economical characteristics. Circa 250 Japanese companies have found their place within the Czech business market [11] which brings about high investments and the creation of new job opportunities. Nevertheless, we should not regard the Japanese as a coherent group (community). According to the gender, the character of their stay differs significantly. Males, mostly managers of Japanese companies, stay for three to five years, often accompanied by their families. On the other hand, there is a prevalence of permanent stay status among Japanese females (often wives of Czechs) whilst up to $80 \%$ of them are unemployed [12].

${ }^{2}$ Theravada, Mahayana and Zen Schools of Buddhism, Church of Unification, ISKCON etc. 
Table 1. Source: Luzny, D., Tlcimukova, P. INTE 2013, http://www.int-e.net/ (to be published).

\begin{tabular}{|c|c|c|c|c|}
\hline \multirow[t]{2}{*}{ Religious group } & \multicolumn{2}{|c|}{ Size (number) } & \multicolumn{2}{|c|}{ Percentage in the population } \\
\hline & 1991 & 2011 & 1991 & 2011 \\
\hline Roman Catholic Church & $4,021,385$ & $1,082,463$ & 39 & 10.3 \\
\hline Czechoslovak Hussite Church & 178,036 & 39,229 & 1.7 & 0.4 \\
\hline Evangelical Church of Czech Brethren & 203,996 & 51,858 & 2 & 0.5 \\
\hline $\begin{array}{l}\text { Silesian Evangelical Church } \\
\text { of the Augsburg Confession }\end{array}$ & 33,130 & 8158 & 0.3 & 0.1 \\
\hline Orthodox & 19,354 & 26,350 & 0.2 & 0.3 \\
\hline Religious Society Jehova’s Witnesses & 14,575 & 13,069 & 0.1 & 0.1 \\
\hline Islam & & 3358 & - & 0 \\
\hline Buddhism & - & 6101 & - & 0.1 \\
\hline Hinduism & - & 2408 & - & 0 \\
\hline Judaism & & 1129 & - & 0 \\
\hline Jediisms & - & 15070 & - & 0.1 \\
\hline $\begin{array}{l}\text { believers, not belonging to any } \\
\text { specific religious organization }\end{array}$ & - & 707649 & & 6.7 \\
\hline Non-believers & $4,112,864$ & $3,604,095$ & 39.9 & 34.2 \\
\hline Unidentified/did not respond & $1,665,617$ & $4,662,455$ & 16.2 & 45.2 \\
\hline
\end{tabular}

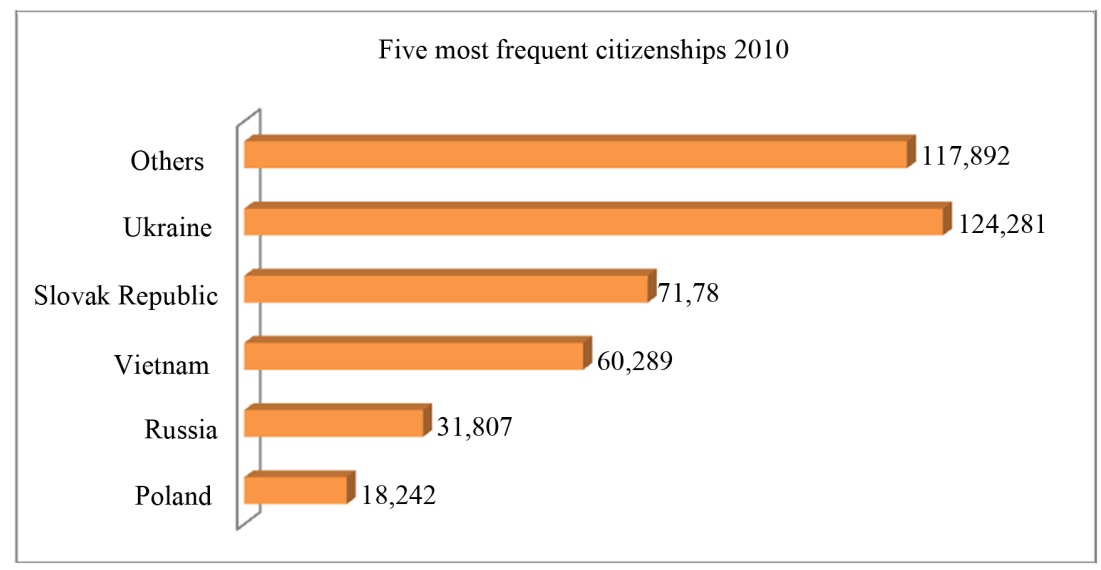

Figure 1. Source: Czech Statistical Office (2011).

Looking beyond the economical factors we could speak on a social level of the almost invisible minority. Due to the circulating character of their labour migration the majority of the Japanese residents leave the country on a horizon of three to five years. Therefore we cannot speak of successful integration into the host society. The minority rather creates parallel social structures on the societal as well as on the community level.

This is one of the reasons I decided to focus mainly on the Japanese living long-term in the Czech Republic. Before I proceed to the data analyses the next paragraphs present some critical remarks and theoretical as well as methodological suggestions concerning Japanese migrants' religiosity inquiries upon which I built my own research strategy.

\section{5. (Japanese) Migrant's Religiosity Research—Some Critical Remarks}

Religion, as a part of socio-cultural equipment that people bring with them when migrating, and its socially 
transformative potential, should be paid attention to; we should take into account both the specifics of different migrant groups as well as considering the social context of the environment into which they migrate. Although the number of Asian migrants in the Czech Republic is increasing constantly, there have been only a few attempts to examine the significance of socio-religious aspects in their lives so far [13].

Moreover, the academic studies on immigration and religion deal almost exclusively with the issue of integration into the host society. The methodological nationalism [14] (often inherently) present in the scholars' attitudes is characterized by the exclusive interest in aspects of integration, marginalization of migrants' voices, preferred quantitative methodology that offers only rough data and categories that neglect the emic structures of meanings which migrants construct.

Reaching beyond the methodological nationalism and reflecting the existence of locally unbounded religious ties, Thomas A. Tweed [2] and Peggy Levitt [15] have proposed new perspectives on the research of religion in a global context. Nevertheless, we should pose the question, why is the research on religiosity of migrants (not only those of Japanese origin) confined exclusively to the institutionalized/organized forms of religion ${ }^{3}$. The theoretical approaches that offer concepts such as individualized religiosity, spirituality etc. remain unexploited and much of the religious phenomena and processes in the post-modern societies remain unrevealed, neglected by the currently dominant sociological discourse. For the purpose of gaining new sociological knowledge of these processes it would be useful to reconsider the scholarly attitudes that bring us to the methodological mile stone where we tend to decide according to the following scheme: belong to a religious community - research/ do not belong to a religious community — not to research.

Inasmuch as the religion is recognised to be a difficult research subject, social scientists should be clear and reflexive about their standpoints and the definitions they build upon (i.e. which definition of religion they choose to use and for what theoretical and methodological purposes). Especially in the case of the religion of Japanese we often encounter explicit tendencies to essentialize the phenomenon. To use the term "Japanese religion" (sg.!) leads to the applied essentialism, as the researchers advert to the idea of common ethnic religion of Japanese migrants [3,4]. In order to avoid such simplifications of the complex phenomenon that religion is, we should examine the structures of meanings that the Japanese and/or Japanese migrants ascribe to the term "religion" and its place within the social networks. To define religion as a flow or a dynamic process of the migrants' negotiation allows us to follow the trajectories of its development and to reveal the transformational nature of religiosity in the context of transnational migration.

It remains a challenge for the scholars to define the nexus of migration and religion in the current global world coherently. Now, the question arises as to how to effectively cope with the raised critique and which epistemological tools can help us to overcome the concrete research shortcoming so far reflected in the studies. Which method and theory would help us to reveal the hidden places of empirical reality and give us answers to the questions posed?

\section{Research Perspectives}

Researchers' attitudes always predetermine the outcomes of the inquiry to a large extent. Since the general research question was: "What role does religion have in the post-immigration lives of the Japanese in the Czech Republic?” it was necessary to reach the data through the inter-personal encounters with the Japanese migrants themselves. My intention was to reveal the character of identity negotiation processes, and the role of religion within, on micro-level, therefore I decided to undertake an investigation based upon qualitative methodology.

Social sciences dispose of different qualitative methods that allow us to reveal new empirical facts and to gain new analytical perspectives and insights that re-built our (sociological) reflections of the world. Nevertheless, every research environment requires specific sensibilities applied by the researcher, so he/she is able to construct the new sociological knowledge upon the gained data.

Regarding the possible misguidance of attitudes so far applied to research on migrant's religiosity, I searched for flexible scholarly tools. What I propose here is a methodology I created and used in my research, which builds upon an approach I named "complementary research attitudes". Such an approach unfolds from the dialectics of the components within the specific research. In praxis, the researcher is obliged to pay attention to the interaction of his/her theoretical and methodological frameworks in every step of the research process (creation

\footnotetext{
${ }^{3}$ In the case of Japanese religiosity much interest has been aroused by controversial Japanese new religious movements (Soka Gakkai International, Kofuku no Kagaku etc.) and the processes of their accommodation outside Japan.
} 
of the research questions, defining and interacting with the research group, analytical outcomes, revision of the theories used, publication etc.) as well as is expected to reflect upon possible new requirements of the researched environment by re-defining the scholarly tools in the course of the research ${ }^{4}$.

The method I propose is based upon methodological anti-machiavelism, and anti-utilitarism. Using these terms I intend to draw the scholars' attention and to specify what Giddens calls “double hermeneutics" [17]. On the methodological level, the researcher should apply environmental, inter-personal and academic sensibilities, so as not to exploit the research field through a lack of circumspection. The approach of methodological antimachiavelism espouses that to reach the goals of the research (answering the research questions, hypothesis verification, creation of a new theory) it is not enough to use the method which allow us to do so. We should search for such a method that would respect the research environment. In other words, the purpose of research does not justify the methodological tools used.

Being aware of religion as a problematic research topic (not exclusively) in the case of the Japanese, in my research among Japanese migrants in the Czech Republic I implemented a "methodologically evasive action" which in practise meant arch data collecting (not asking about religion directly). The research was based on in-depth interviews with 18 respondents (8 interviews were recorded). The majority of the respondents were Japanese living (or having the intention to live) long-term in the Czech Republic while more than half were females. The contacts to the respondents were gained mainly through the method of the snow ball and contacting an unknown person. In most of the cases, several informal interviews anticipated the final recorded one. Only one of the respondents was overly religious (a member of a religious organisation), the rest claimed no religious affiliation at the beginning of the research.

A hybrid of Jean-Claude Kaufmanns' understanding interview and narrative ethnography served as a bridge to gain the desired data. As the complementary research attitude anticipates, there was no structured scheme of the interviews I conducted. Rather the aim was to follow and react on what the respondents were relating to in their post-migrants stories. Our dialogs were the source of knowledge which allowed me to co-exist in the migrants' social space and simultaneously analyse it in the social space of social science. To use the hybrid of understanding and narrative interview in praxis meant that I asked respondents to tell me a story of their post-immigrant lives in the Czech Republic. In the course of the interview I was actively participating, reacting specifically when referred to religion. Thus it was possible to find out whether the topic of religion will ever be schematised and how. However, it was important to remain faithful to the narrative character of the interview, i.e. to let the migrant tell me the story of that particular period of his/her life.

As a theoretical framework I used the theories of transnationalism which draw attention to new phenomena in contemporary migration processes - constitution and maintenance of more than one home and construction of transnational identity, both independently on existing nation-state boarders. Contemporary qualitative researches which draw on the theories of transnationalism are almost exclusively restrained to the analysis of the ethnic identities of migrants. What a surprise it was when I realised how often and intensively the respondents related to it themselves! What does it mean to be Japanese, then? For the analytical purposes I used the concept of ethnic identity and I re-constructed what were the respondent referring to when mentioning their "Japaneseness" in our interview.

\section{7. "Aha, I Am Japanese!" What Do We Mean by Ethnic Identity?}

In sociology, we conceptualise the identities as continuously negotiating constructions and re-produced knowledge about the Self. Relational interpretation of identities determines the concept and fluid and dynamic. Thus we must ask, what respondents were relating to when referring to themselves as Japanese. As I have revealed, a crucial element in negotiating the ethnic identity was the intended length of their stay in the Czech Republic. Confronted with the Czech society they mentioned they perceived their differentness, in some cases for the first time in their lives. As Chico expressed herself:

When I arrived in Prague I realized I am really Japanese. That means I certainly like the Czech Republic, Czech culture and so on, but I always compare the differences or *.. "Aha, this functions this way" (completely different than in Japan) and so on. Each time I feel or realize this I think: “Aha, I am Japanese!”

A long-lasting confrontation of Japanese migrants with the Others (Czechs) pervasively influenced the way

${ }^{4}$ The understanding interview supports the idea of methodological inventiveness and the academic tools during the research process openness [16, p. 47]. 
they interpreted themselves. They started to deal with the question "who am I-Japanese or Czech?"

The analysis revealed migrants to negotiate their ethnic identity/otherness at two discursive levels:

1) As a physical difference: referring to their bodies as to a "handicap" of the full integration into the host society (e.g. "Although I try hard I will never be the same as the Czechs. I will never be white.”, "We Japanese are different, for example we need different food because our digestive system is differently developed than those of Europeans.", "When I go on the streets here people look at me $\cdots$ because I look different-I look Asian.")

2) As a socio-cultural difference: referring to the collective habits, behaviour and social acting.

Based on the reflection of the empirical data I draft the first theoretical outcome as follows: 1) Ethnic identities (pl.!) "as they appear in migrants" interpretation, do not function as a separate stable category 2) they overlap with other types of social identities 3) which are influenced by socio-cultural environment 4) and are steadily negotiated during the process of (self-)reflexive discursive practices.

\section{What about Religion?}

Now, we must ask whether, within the multiplicity of identities, Japanese migrants also tend to construct religious identities, which would form their lives in the sense of transmigration. So far, there have been researches conducted on role of religion in lives of transmigrants as members of a religious organisation [2]. In this sense my research group was not coherent and I dealed with both individualized and organised religiosity. The method I applied allowed the respondents to decide themselves whether and in which context to include religion (as I operationalized it as an empty concept) into the narrative. The empty concept was to be filled with their statements. Opposing the initial statements where the respondents basically regarded themselves as non-religious or atheists, more than a half of them were constructing religious identities in the course of the interview. Threepoint typology reflects when the topic appeared in the scope of narrative:

1) inherent part of narrative (member of Soka Gakkai International)

2) extended response (though firstly claiming no affiliation to any religion for them and Japanese generally)

3) off recording

Despite of the initial claims, the analyses shows that in some post-immigrant lives of the Japanese the religion plays an important role. Respondents were explicitly referring to "religion" as to: a general phenomenon (religion in Japan, family and religion), concrete traditions (various Buddhist schools, Shinto), practices (shrines' visiting, funerals) and ideas (Buddhahood, fellow feeling).

The research reveals one unique aspect of self-reflection of Japanese and their relationship to religion. They tend to create a collective ethnic-based non-religious (religion rejecting) identity. In other words, they mostly assert that "the Japanese are not religious". However, this symbolical collective non-religious identity was often re-interpreted and re-constructed during the interviews. At the same time, (with one exception) they defined themselves as not religious persons. Although claiming collective as well as individual non-religiosity, in the course of the interviews this idea was shattered and religion was revealed as an important part of their lives (in ways articulated above).

The aim was to conceptualize the term religion as it was constructed in the interview and to re-construct the religious identity creation processes through the data analyses. Since I conceive religion as a part of socio-cultural domain of life, the religious identities should be interpreted as a part of other socio-cultural identities, continuously negotiated by actors (migrants), and thus neither as an independent (but inter-related and fragmented) nor a stable category.

I expose the above described individualized identities as fragmented, a mosaic made up of different aspects that were interpreted as religious. The character of fragmentation in case of respondents with an affiliation to a religious organisation (Soka Gakkai International) consists of something slightly different. Unlike the others who were creating an individualized religious mosaic, Chik's already consciously existing and coherent reli gious identity had been confronting other socio-cultural types of identities. Thus her coherent religious identity was also interpreted as influenced and modified, for example, by different cultural specifics of the Czech Republic.

It was not the aim of the research to deal with the topic of integration; rather I intended to answer the questions as to how the religious identity is constructed in the narratives of Japanese migrants and what role religion has in their lives as migrants. I was particularly concerned whether their religious identity (both institutionalized and individualized) would dispose of any transnational character. 
Based on my findings, a theoretical model of the construction of migrant's religious identities can be proposed: Religious identities (both institutionalized and individualized) interpreted as a part of other socio-cultural types of identities, (their aspects) steadily negotiated, and thus neither a separate nor a stable category. Religious identities are thus fragmented in the sense of an unfinished process of negotiating fragments of sociocultural elements.

\section{Conclusions: Empirical Research Outcomes-Theoretical Revisions}

But can we label these religious identities as transnational? Based on what presumptions do we indicate the aspect of transnationalism within them?

Several outcomes can be outlined regarding transnationalism and the religion nexus. Although the method of inquiry allows some migrants to create a religious identity, not all proclaim to have any (either individualized or institutionalized). Nor do all of them dispose of transnational identity in the sense that they would create and maintain two or more symbolic homes in different countries. The lives of some of them are restricted to the place of their contemporary stay or otherwise, they do not intend to maintain any stable home outside Japan (short-term stay). Therefore I interpret transnationalism as a special phenomenon which does not automatically occur in case of any contemporarily migrating person. Moreover, rather than referring to a transnational identity, we should speak of the plurality of transnational identities, one of which is religious.

As my empirical investigation shows, there are a few interesting findings about religion as a transnational phenomenon that can have an impact on lives of Japanese migrants in the Czech Republic. I argue that, to some extent, the individualized religious identities can be referred to as transnational as they reach beyond any terrestrial boarder without problem. At the same time, we must be aware that, as complex as any individualized religious identity can be, its specific elements can be strictly bounded to a (symbolic) place. In the case of the Japanese, this applies especially to Buddhist burials, ritual visits to Shinto shrines etc. In these cases, we can speak of locally restricted religious practices for which to practise Japanese have to return to Japan. On the other hand, being a member of a transnational religious organisation (e.g. Soka Gakkai International) might require acting in a nationally unrestricted manner. It does not mean being unaware of national socio-culture specifics. Rather it involves the explicit transmission of an overly religious identity which, due to the processes of negotiation, includes also its transformation. In the case of the Soka Gakkai International religious migrant, the religious identity was explicitly articulated from the beginning. It is desired by the organisation whose member creates a global (transnational) identity. I argue that the migrant went through the same process of negotiation and fragmentary identity transformation as the other migrants who constructed an individual identity during the interview. At the same time, the religious identity of the SGI member can be interpreted as transnational, embodying religious ties that go beyond local/national boundaries and high reflexivity of the local religious specifics.

Based on the findings, I assume that the creation of religious identities is only to some extent possible to be interpreted as the creation of transnational religious identities. The global religions offer us a good study material on how the transnational religious identities are created; nevertheless, we should also turn our attention to the individualized religiosity, since the created religious mosaic might be surprisingly rich and influential on lives of migrants. With help of a suitable methodology, we might uncover important processes concerning the negotiation of religious identities on the individual level. In other words, the widely claimed non-religiosity of the Japanese might be uncovered as strongly individualized or locally bounded religiosity. Simultaneously, analysing the aspect of transnationalism within religious identities, both individualized and institutionalized, we should be able to identify the concrete socio-cultural elements that are of a transnational character, as not to simplify the complexity of religious identities and the processes of its negotiation.

\section{Acknowledgements}

I would like to express my very great appreciation to Dusan Luzny for his advice and support during the research and writing process. I also wish to thank all my respondents for their highly appreciated cooperation.

\section{References}

[1] Havlíček, J. (2012). Cesty božstev: Otázka interpretace náboženství a nacionalismu v moderním Japonsku. Nový Orient, Praha. 
[2] Tweed, T.A. (2006) Crossing and dwelling. A theory of religion. President and Fellows of Harvard College.

[3] Befu, H. (2001) The global context of Japan outside Japan. In: Befu, H. and Guichard-Anguis, S., Eds., Globalizing Japan: Ethnography of the Japanese Presence in Asia, Europe, and America, Routledge, London, 3-22.

[4] Earhart, B.H. (1999) Japonské náboženství: Mnoho tradic na jedné svaté cestě. Prostor, Praha.

[5] (2013) The Asia-Pacific Journal: Japan Focus. Ethnic Identity, Culture, and Race: Japanese and Nikkei at Home and Abroad. http://japanfocus.org/-Nobuko-Adachi/3410

[6] Fujita, Y. (2009) Cultural migrants from Japan: Youth, media, and migration in New York and London. Lexington Books, New York.

[7] Matsue, R.Y. (2006) Religious activities among the Japanese-Brazilian. In: Kumar, P.P., Ed., Religious Pluralism in the Diaspora, Brill, Leiden, 121-146.

[8] Clarke, P.B. (1999) Japanese new religious movements. In: Wilson, B. and Cresswell, J., Eds., New Religious Movement: Challenge and Response, Routledge, London, 197-210.

[9] Nešpor, Z.R. and Lužný, D. (2012) Sociologie náboženství. Portál, Praha.

[10] Lužný, D. (2010) Globalizace a sociologie náboženství. In: Lužný, D., Ed., Individualizace Náboženství a Identita: Poznámky k Současné Sociologii Náboženství, Malevrn, Praha, 5-35.

[11] (2013) Bussiness Info. Japonsko: Obchodní a ekonomická spolupráce v ČR. http://www.businessinfo.cz/cs/clanky/japonsko-obchodni-a-ekonomicka-spoluprace-s-cr-18637.html

[12] Barešová, I. (2010) Socio-kulturní specifika japonské komunity v České republice. In: Barešová, I., Ed., Současná Problematika Východoasijských Menšin v České Republice, UPOL, Olomouc, 43-51.

[13] Topinka, D. (2010) Integrace muslimů/imigrantů do “české” společnosti. In: Lužný, D., Ed., Individualizace Náboženství a Identita: Poznámky k Současné Sociologii Náboženství, Malevrn, Praha, 276-293.

[14] Wimmer, A. and Glick Schiller, N. (2002) Methodological nationalism and beyond. Nation-state building, migration and the social sciences. Global Networks, 2, 301-334. http://dx.doi.org/10.1111/1471-0374.00043

[15] Levitt, P. (2007) God needs no passport: Immigrants and the changing American religious landscape. The New Press, New York.

[16] Kaufmann, J.C. (2010) Chápající rozhovor. SLON, Praha.

[17] Giddens, A. (1987) Social theory and modern sociology. Polity Press, Cambridge. 